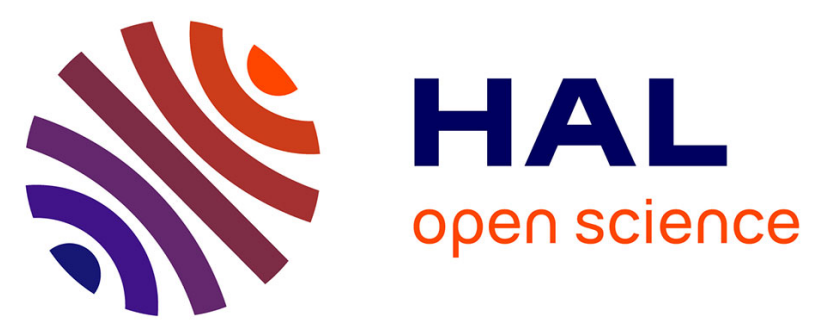

\title{
Investigations into an outbreak of corvid respiratory disease associated with Pasteurella multocida
}

Benjamin William Strugnell, Mark Dagleish, Colin Bayne, Mike Browne, Heather Ainsworth, Robin a J Nicholas, Alisdair Wood, Chris Hodgson

\section{- To cite this version:}

Benjamin William Strugnell, Mark Dagleish, Colin Bayne, Mike Browne, Heather Ainsworth, et al.. Investigations into an outbreak of corvid respiratory disease associated with Pasteurella multocida. Avian Pathology, 2011, 40 (03), pp.329-336. 10.1080/03079457.2011.571659 . hal-00710056

\section{HAL Id: hal-00710056 https://hal.science/hal-00710056}

Submitted on 20 Jun 2012

HAL is a multi-disciplinary open access archive for the deposit and dissemination of scientific research documents, whether they are published or not. The documents may come from teaching and research institutions in France or abroad, or from public or private research centers.
L'archive ouverte pluridisciplinaire HAL, est destinée au dépôt et à la diffusion de documents scientifiques de niveau recherche, publiés ou non, émanant des établissements d'enseignement et de recherche français ou étrangers, des laboratoires publics ou privés. 


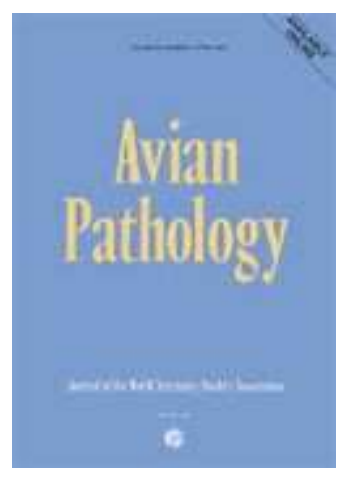

\section{Investigations into an outbreak of corvid respiratory disease associated with Pasteurella multocida}

\begin{tabular}{|r|l|}
\hline Journal: & Avian Pathology \\
\hline Manuscript ID: & CAVP-2010-0168.R2 \\
\hline Manuscript Type: & Original Research Paper \\
\hline Date Submitted by the & 28-Jan-2011 \\
\hline Complete List of Authors: & $\begin{array}{l}\text { Strugnell, Benjamin; Veterinary laboratories Agency, Thirsk } \\
\text { Regional laboratory } \\
\text { Dagleish, Mark; Moredun Research Institute, Pathology department } \\
\text { Bayne, Colin; Moredun Research Institute, Pathology department } \\
\text { Browne, Mike; British Trust for Ornithology } \\
\text { Ainsworth, Heather; Veterinary Laboratories Agency, Bury St. } \\
\text { Edmunds regional laboratory } \\
\text { Nicholas, Robin; Veterinary Laboratories Agency, Statutory and } \\
\text { Exotic Bacteria } \\
\text { Wood, Alisdair; Veterinary Laboratories Agency, Lasswade } \\
\text { Hodgson, Chris; Moredun Research Institute, Pathology department }\end{array}$ \\
\hline Keywords: & \begin{tabular}{l} 
corvid, pasteurella multocida, respiratory disease, UK \\
\hline
\end{tabular} \\
\hline
\end{tabular}

\section{SCHOLARONE \\ Manuscripts}


Investigations into an outbreak of corvid respiratory disease associated with Pasteurella multocida

${ }^{1}$ Strugnell, B., ${ }^{2}$ Dagleish, M.P., ${ }^{2}$ Bayne, C.W., ${ }^{3}$ Browne, M., ${ }^{4}$ Ainsworth, H., ${ }^{5}$ Nicholas, R.A.J., ${ }^{6}$ Wood, A. and ${ }^{2}$ Hodgson, J.C.

${ }^{I}$ VLA Thirsk, West House, Station Road, Thirsk, North Yorkshire YO7 1PZ. ${ }^{2}$ Moredun Research Institute, Pentlands Science Park, Bush Loan, Penicuik, Midlothian EH26 OPZ. ${ }^{3}$ British Trust for Ornithology (BTO), BTO Regional Representative for Yorkshire (Harrogate). ${ }^{4}$ VLA Bury St. Edmunds, Rougham Hill, Bury St. Edmunds, Suffolk IP33 2RX. ${ }^{5}$ Mycoplasma Group, VLA Weybridge, New Haw, Addlestone, Surrey KT15 3NB.

${ }^{6}$ VLA Lasswade, Pentlands Science Park, Bush Loan, Penicuik, Midlothian EH26 OPZ.

Short title: fowl cholera

Received: 28 January 2011

Author for correspondence: Ben Strugnell

email: b.strugnell@vla.defra.gsi.gov.uk

Tel: 01845522065

Fax: 01845525224 


\begin{abstract}
The possible cause of disease and mortality in corvids on an outdoor pig unit in the north of England between August 2007 to March 2008 was investigated. Nine carrion crows (Corvus corone corone) and 9 rooks (Corvus frugilegus), comprising five live-caught birds with clinical signs of respiratory disease, one live-caught bird without respiratory disease, and 12 birds submitted dead were examined. Clinical signs, gross and histopathological examination, microbiology and toxicology indicated that Pasteurella multocida infection was the cause of disease. Molecular and serotyping analyses showed that $P$. multocida isolates (obtained from live-caught birds with clinical respiratory disease) were all capsular type $\mathrm{F}$ with a mix of somatic serotypes 3, 4 and 7. Immunohistochemistry (IHC) increased the diagnostic sensitivity of the analysis and detected P. multocida within the pulmonary lesions of all affected live-caught birds and 10 of 12 birds found dead. These findings suggest that wild corvids in the UK can suffer from lung pathology associated with $P$. multocida and, as potential vectors of $P$. multocida, may pose a risk to domestic poultry.
\end{abstract}




\section{Introduction}

The Gram-negative bacterium Pasteurella multocida comprises 5 capsule serogroups (A, B, D, E and F) and 16 somatic serotypes. Serogroup A is isolated most frequently in fowl cholera, a disease of major economic importance in commercially reared birds and outbreaks in England are associated primarily with somatic serotypes 1,3 and 3,4 (Rhoades \& Rimler, 1990). Molecular typing has shown that wild birds, and possibly mammals, may be the source of infection in some disease outbreaks in commercial poultry (Christensen \& Bisgaard, 2000). The species and age of affected birds, their environment and the strain of $P$. multocida involved influence the severity and incidence of disease and mortality varies from a few to 100 percent (Rimler \& Glisson, 1997).

Corvids are intelligent, highly adaptable birds which have frequently capitalised on changes in agriculture and land use resulting in thriving populations, often in close proximity to farmed livestock and crops. Outdoor pig units are a particular niche to which corvids have become adapted (Marchant \& Gregory, 1999). However, there is little information on the susceptibility of corvids to, or their ability to transmit, bacterial disease such as fowl cholera. The aim of this study was to investigate the aetiology of disease among corvids found either dead or displaying clinical signs of respiratory disease. Similar outbreaks of disease have been reported previously in the UK, sometimes referred to as corvid respiratory disease, without a definitive cause being determined (Pennycott 2005).

\section{Materials \& Methods}


Background, case definition, inclusion criteria and clinical signs. In August 2007, the carcases of seven rooks (Corvus frugilegus, birds 1-7) were submitted to the Veterinary Laboratories Agency (VLA) Thirsk regional laboratory for post-mortem examination under the UK Department of Environment, Food and Rural Affairs (Defra) Wildlife Incident Investigation Scheme (WIIS) and the VLA Diseases of Wildlife Scheme (VLADoWS). They represented an estimated 30 birds found dead in a 1.62 hectare wood comprised of deciduous trees, mainly ash, beech and oak, adjacent to a 1000-sow outdoor weaner producer pig unit near York, UK. Over the next six months, amid continuing mortality in this population of corvids, there were a further eight submissions (Table 1), comprising: three carrion crows (birds 9, $11 \& 14$ ) and two rooks (birds $8 \& 12$ ) caught live showing clinical signs of respiratory disease; one live carrion crow (with a humeral fracture) showing no clinical signs of respiratory disease (bird 15) and five carrion crows found dead (birds 10, 13, 16, 17 \&18). Live-caught birds were held in a large crow trap (for at most 8 hours) and were delivered alive to VLA Thirsk except bird 12 which died in the trap. Clinical signs included moderate to severe dyspnoea, a reduced ability or inability to fly, a snicking cough and weakness (Table 1). Disease was considered to have been progressive, culminating in birds that were either easy to catch or found dead.

Ornithological and natural history investigations. The site was visited on six occasions at regular intervals during the period from September 2007 until June 2008, in collaboration with the British Trust for Ornithology (BTO), to determine the feeding, roosting and other behaviours of corvids and other wild birds. Estimates of the sizes of corvid populations, population dynamics and interactions were performed subjectively by an experienced local ornithologist (M. Browne). 
Gross post-mortem examination. Post-mortem examinations were performed on all 18 birds. Live birds were euthanased with an intravenous overdose of pentobarbitone (Euthatal, Merial Animal Health) via a brachial vein. Samples of lung from at least one bird from all submissions (except submission 6), and other tissues abnormal on gross examination (Table 1), were placed into $10 \%$ formal saline for histopathology. Where indicated (Table 1) samples for bacteriological, virological and toxicological examination were collected from each bird using aseptic (seared surface) techniques. Selection of tissues for bacteriology was on the basis of abnormal appearance as determined by the pathologist performing the postmortem examination (BS) and samples plated out immediately (see below). A different range of tissues was therefore taken from each bird. Tissue samples for virological examination were stored at $-80^{\circ} \mathrm{C}$ (maximum of 3 weeks) prior to investigation and those for toxicology stored at $-80^{\circ} \mathrm{C}$ until required.

Microbiology. Each sample was concomitantly cultured on sheep blood agar (SBA, Oxoid, Basingstoke, UK), SBA with a 'nurse streak' of Staphylococcus intermedius, SBA cultured in $5 \% \mathrm{CO}_{2}$ or MacConkey's agar (Oxoid). Direct and enrichment cultures for Salmonella using brilliant green agar (Oxoid) and Selenite broth ((Oxoid) were performed on pooled large intestinal contents from the first four submissions (birds 1-7 in 2 pools; 8-11 individually). Fungal enrichment cultures were performed on all samples of lung and/or air sac which were selected for bacterial cultures using Sabourard's agar (SAB, Oxoid) alone or containing penicillin and streptomycin (SABA, Oxoid). Bacteria were identified using standard laboratory techniques. $P$. multocida was identified by characteristic smell and colonial morphology, Gram staining and microscopic appearance, lack of growth on MacConkey's agar, a positive indole reaction and a negative urease reaction (Blackall \& Norskov-Lauritsen 2008; Dziva et al 2008). Samples of lung, airsac and/or sinus at the discretion of the 
pathologist from all but the first seven birds (omitted due to autolysis) were placed in Friss pre-enrichment broth (Bradbury, 1998) and checked for Mycoplasma growth at 24 and 48hrs, then at weekly intervals for 4 weeks. Positive cultures were identified using denaturing gradient gel electrophoresis (McAuliffe et al., 2005).

Bacterial DNA extraction. Isolated bacteria were cultured overnight in brain heart infusion (BHI) broth (Oxoid, UK) at $37^{\circ} \mathrm{C}$ and DNA extracted from $1 \mathrm{ml}$ of suspension using a DNeasy kit (Qiagen Ltd., Crawley, UK) according to manufacturer's instructions and quantified (NanoDrop Spectrophotometer, Nanodrop Products, Wilmington, USA). Samples were stored at $-20^{\circ} \mathrm{C}$ until required.

\section{Determination of capsule type, serotype and presence of virulence associated genes.}

Isolates of $P$. multocida were analysed by PCR for the presence of species-specific sequence KMT1 (Townsend et al., 1998), capsule biosynthesis genes capA, $B, D, E \& F$ (Townsend et $a l ., 2001)$ and the virulence associated genes $p f h A, h g b B$ (Ewers et al., 2006), tbpA (Ogunnariwo \& Schryvers, 2001) and toxA (Lichtensteiger et al., 1996), using amplification conditions and primer sequences described by these authors. Primers were tested against positive control isolates which had been typed by conventional methods to confirm capsule type. For all PCR reactions $50 \mathrm{ng}$ of extracted DNA were taken as template and added to the reaction mixture $(50 \mu \mathrm{l})$ containing $0.2 \mu \mathrm{M}$ of each primer (Eurofins MWG Operon, Wolverhampton, UK), $0.2 \mathrm{mM}$ of each of the four deoxynucleotide triphosphatases (Invitrogen Ltd., Paisley, UK), $1 \times$ PCR buffer, $1.5 \mathrm{mM} \mathrm{MgCl}_{2}$ (except for capA PCR reactions which contained $2 \mathrm{mM} \mathrm{MgCl}$ ) and 1 unit of Platinum Taq (Invitrogen). Samples were subjected to 35 cycles of amplification in a Lehne Thermocycler TC-3000 Techne Thermal cycler (Bibby Scientific Ltd., Staffordshire, UK). Amplified products were analysed 
by electrophoresis in a $1.5 \%$ Tris acetate EDTA agarose gel, stained with Gel Red (Cambridge Biosciences, Cambridge, UK), visualised under UV transillumination and photographed. Serotypes of $P$. multocida isolates from birds 8, 9, 12 and 14 were determined by conventional methods by VLA, Lasswade, UK.

Virology. A real time PCR for the detection of the matrix gene of influenza A virus (Anon, 2006) was performed separately on two sample sets from the first 8 birds examined (birds 18, submissions 1 and 2) comprising pooled bulk viscera; brain, liver, spleen, lung, kidney, trachea and intestine. For birds 1-11 samples of brain and kidney were tested for West Nile virus (WNV) by reverse transcription-polymerase chain reaction employing specific primers directed at the $\mathrm{C}$-terminal of the $\mathrm{C}$ gene and the $\mathrm{N}$-terminal of the prM gene and via $20 \%$ (w/v) suspensions of the same samples of brain and kidney after two passages in Vero C1008 (ATCC) cells (Gough et al., 1998; Phipps et al., 2007). Scanning electron microscopy was performed on selected tissues from bird 8 (pooled bursa and spleen, and a pool of kidney and lung) to investigate the presence of other viruses. $3 \mathrm{~mm}$ Copper/Rhodium (100 $\mu \mathrm{m}$ mesh) support grids were used for the analyses. Each grid was pre-treated by immersing into $0.4 \%$ formvar in chloroform (w/v), followed by carbon coating, to provide a stable sample platform. Treatment was then completed, by subjecting each grid to plasma glow discharge, to ensure the grids were highly hydrophilic. Each sample analysed (approx. $0.25 \mathrm{~cm}^{3}$ ) was ground in $2 \mathrm{~cm}^{3}$ of $0.1 \mathrm{M}$ Sorenson's phosphate buffer ( $\mathrm{pH}$ 6.6), to form a suspension. An aliquot of each sample suspension $(50 \mu \mathrm{l})$ was pipetted onto a piece of dental wax and a support grid was then placed copper side upwards onto the aliquot for 30 seconds and excess sample removed by wicking dry. Each grid was then placed as before onto a drop of $2 \%$ phosphotungstic acid (w/v) ( $\mathrm{pH}$ 6.6), for 10 seconds to counter-stain the grid and again excess stain removed by wicking dry. Analysis of each sample was undertaken on a Phillips 
CM10 microscope at $\times 34,000$ magnification, at $80 \mathrm{kV}$. Analysis time was standardised to 20 minutes viewing of the sample grid or assessment of 25 grid squares for the presence of virus particles, whichever was the shortest

Histopathology and Immunohistochemistry. Tissues for histopathology from 17 birds (Table 2) were processed routinely to wax blocks within 72 hours of collection. Sections (5 $\mu \mathrm{m})$ were mounted on glass microscope slides and stained with haematoxylin and eosin or subjected to Gram's stain (ProLab Diagnostics, Neston, UK) for bacteria or Grocott Gomori methenamine silver (GGMS) for fungal hyphae.

Further sections, including duplicates for negative control preparations, were mounted on Superfrost ${ }^{\mathrm{TM}}$ slides (Menzel-Gläser, Braunschweig, Germany) and subjected to immunohistochemistry (IHC) with polyclonal antiserum raised in a rabbit against $P$. multocida A:3 as described previously (Dagleish et al., 2010). A positive control sample consisting of a section of lung from a calf infected experimentally with $P$. multocida A:3 and containing typical lesions of suppurative broncho-pneumonia was included for comparison of the pattern of immunolabelling with that of $P$. multocida serotype $\mathrm{F}$ isolated from crows in this study. All slides were blind-coded and examined for morphological lesions and the presence and distribution of immunolabelling relative to histological lesions.

Toxicology. Screens for alpha chloralose and rodenticides were performed under the Wildlife Incident Investigation Scheme at the Central Science Laboratories, York, UK, using the methods decribed by Brown et al (2005), on pooled kidneys and livers respectively from birds $1,3 \& 4$ (the least autolysed in submission 1 ). 


\section{Results}

Ornithological investigations and observations. The corvid population at the site was estimated at 200-300 birds comprising $65 \%$ carrion crows, $25 \%$ rooks and $10 \%$ jackdaws (Corvus monedula). The nesting capacity of the wood could not accommodate this number of birds suggesting that a large proportion travelled daily some considerable distance to the farm. Approximately $60 \%$ of the birds found dead were in and around the wood, the remainder on grass pastures and nearby pig paddocks where it was common for large flocks of all 3 species to forage together.

Gross post-mortem findings. The commonest lesion, present in all 17 birds with lesions suggestive of infectious disease (Table 1), was fibrinous proliferation on at least one serosal surface (pericarditis, perihepatitis or airsacculitis). No gross lesions were present in the viscera of bird 15, live-caught due to a simple fracture of the left humerus with no clinical signs of respiratory disease. Airsacculitis (Figure 1) was present in 12 (70\%) of the 17 affected birds. Necrotising pneumonia was seen in 3 (19\%) of the 17 diseased birds, including bird 12 (Figure 2) which died awaiting collection. In most cases the gizzards were empty or contained little food and in 3 cases (birds 5, 8 and 14) ascarid worms were present. Ectoparasites (lice) were noted on live-caught birds 8, 9 and 11. Cestodes were a common finding in the small and large intestines (6 (66\%) of 9 rooks; birds 2, 4, 5, 7, 8 and 12 and 3 (33\%) of 9 carrion crows; birds 9, 14 and 11). The findings suggested a spectrum of disease from relatively acute (e.g. bird 17) to chronic (e.g. bird 13) pneumonia and polyserositis. No gross lesions suggestive of haemorrhagic meningitis, congestion of meningeal vessels or brain oedema were present in any of the birds examined. 
Microbiological findings. P. multocida was isolated from at least one of either the lung, airsac, sinus, heart blood, liver or pericardium in all five affected live-caught birds (birds 8,9 , 11, 12 and 14) (Table 1). In bird 9 pure growths of $P$. multocida were recovered from the lung, air sac, liver and heart blood indicative of a septicaemic distribution. Salmonella spp. were not isolated from large intestinal contents from birds 1-11 using direct or enrichment culture techniques and no further Salmonella cultures were performed. Escherichia coli, Proteus spp. and other saprophytic bacteria were recovered only from birds found dead (Table 1). Fungal cultures were negative from all tissues examined.

Capsular type, virulence associated genes and serotype. Four P. multocida isolates (from birds 8, 9, 12 \&14) were available for further testing All four demonstrated the presence of $c a p F$ capsule gene only, the species specific gene sequence KMT1 and virulence associated genes haemoglobin binding protein $(h g b B)$ and the filamentous haemagglutinin $(p f h A)$. However, transferrin binding protein gene $(t b p A)$ and dermonecrotoxin gene toxA were not detected. Somatic serotypes were 4 (bird 8), 3,4,7 (bird 9) and 3 (bird 12). The isolate from bird 14 failed to type.

Mycoplasma enrichment cultures. Four different Mycoplasma species (M. gallopavonis, M. gallinarum, M. colomborale, and M. sturni, Table 1) were identified. Neither $M$. gallisepticum nor M. synoviae were isolated from any sample.

Virology. All samples examined for WNV and High Pathogenicity Avian Influenza (HPAI) were negative and no other viruses were identified in the cell cultures performed to detect WNV. No virus particles were seen on electron microscopy where performed. Testing for 
WNV ceased after the first 11 birds proved negative on the basis of a low risk during the winter months (little mosquito activity) and a lack of consistent gross and histopathological findings. The EU target species list for HPAI surveillance (Anon 2010a) does not feature corvids so this testing was also restricted to the first two submissions on the basis of low risk and likelihood. Furthermore, histopathological lesions did not suggest avian influenza.

Toxicological findings. Samples of kidney for alpha chloralose and liver for rodenticides were all negative. Further samples for toxicology were retained but not tested on the basis that the lesions were more typical of an infectious process.

Histopathology and Immunohistochemistry. Pneumonia and/or air sacculitis was the most consistent lesion in the birds found dead or live-caught with clinical signs of respiratory disease. The character of the pneumonia varied between granulocytic and fibrinogranulocytic both with and without areas of necrosis (Figure 3). Positive labelling for $P$. multocida was present in the lungs (Figures $4 \mathrm{a} \& \mathrm{~b}$ ) and/or air sacs of all but one of the affected birds examined by specific IHC (Table 2). Bird 17 did not have pneumonia or air sacculitis but a small focus of necrosis present in the lung was positive for P. multocida by IHC. Gram-negative coccobacillary bacterial colonies present extra-cellularly and also within the foamy cytoplasm of macrophages within the lungs and air sacs of some birds were positive for P. multocida by IHC. Bird 15 had a mild cholangiohepatitis. However, no significant lesions were found in the lung, brain or spleen and all tissues were devoid of immunolabelling in this bird. All negative control preparations were devoid of labelling. Nematode parasite profiles were present in the respiratory systems of three birds and a trematode in one (Table 2). No fungal hyphae or other fungal forms were present in any of 
the tissues examined using special stains (GGMS) nor any structures suggestive of viral inclusions in the bursas or spleens that were available for examination.

\section{Discussion}

There are early reports of disease in wild corvids from the UK (Keymer, 1958; McDairmid, 1965) but detailed and recent descriptions are lacking. A syndrome of 'corvid respiratory disease' featuring varying degrees of fibrinous airsacculitis, perihepatitis, pericarditis and pneumonia has been reported (Pennycott, 2005) but most cases were submitted dead and no consistent aetiology was identified.

In this study P. multocida was isolated from the five corvids displaying clinical signs of respiratory disease which were submitted live. All had gross lesions in the respiratory tract. In all but two of the birds submitted dead, Gram-negative coccobaccilli bacteria were associated intimately with the pulmonary histological lesions and showed positive labelling for $P$. multocida by IHC. No gross or histological pulmonary lesions, immunolabelling or isolation of $P$. multocida were observed in a live-submitted bird that did not have clinical signs of respiratory disease. Samples from further birds unaffected by respiratory disease was unfortunately not available. Taken together, these results suggest that $P$. multocida was the cause of the pathology.

It was unusual for P. multocida to type only as serogroup F, as avian isolates analysed by traditional methods are more usually reported as serogroup A (Christensen \& Bisgaard, 2000). However, a comparison of PCR and conventional methods for typing avian isolates of P. multocida, including serogroup F, showed good agreement (Shivachandra et al., 2006) and our findings may reflect the greater discrimination between serogroups possible with PCR, 
highlighted in a study when a proportion of avian $P$. multocida isolates characterised previously by traditional methods as serogroup A were shown by PCR to belong to the closely related serogroup F (Townsend et al., 2001).

The failure to isolate $P$. multocida from birds found dead was surprising as others have isolated it readily from carcases of birds which have succumbed to fowl cholera (Glisson et al 2008; Dziva et al., 2008). It may have been that the strain of $P$. multocida involved was sensitive to changes in temperature, $\mathrm{pH}$ and/or other factors as well as competition from other species of bacteria proliferating post-mortem, especially if bacterial loads were low in this chronic manifestation of disease (see below). Future studies of similar disease outbreaks may benefit from using PCR techniques in addition to bacterial culture to detect $P$. multocida within tissue samples although the technique does not allow the specific localisation within lesions obtainable with IHC.

Corvids have been reported as becoming infected with $P$. multocida after feeding on the carcases of birds which have recently succumbed to fowl cholera and in these reports, the disease course in corvids is longer than in waterfowl. (Zinkl et al., 1977; Taylor \& Pence, 1981). This observation is consistent with our findings where sometimes progressive clinical signs were seen in affected corvids, and histopathological findings showed a chronic disease course. The feeding adaptability and ubiquity of scavenging birds such as corvids makes contact between them and domestic species likely and creates a risk of disease transmission from diseased or sub-clinically affected birds. There is experimental and epidemiological evidence to suggest that in some outbreaks of disease in domestic poultry wild birds were responsible for introducing infection (Snipes et al., 1988, Petersen et al., 2001), and risks may be increased if disease (and shedding) is chronic. Challenge studies using the $P$. multocida $\mathrm{F}$ isolates from corvids in this series would establish their potential pathogenicity to domestic poultry and therefore the risk infected corvids may pose. However, this work was 
out-with the scope of this study. In the USA corvids are considered important in the epidemiology of WNV as they are highly susceptible, developing a substantial viraemia prior to death (Reisen et al., 2006; (Murray et al, 2010). In Western Europe reports of human fatalities due to encephalitis caused by this disease have been recentlly reported (Papa et al 2010), and surveillance for this agent is important (Zoller et al. 2010). However, to date WNV has not been detected in the UK and all tests in this series were negative.

Although several of the birds were parasitised by lice, ascarid nematodes and cestodes, burdens were low and not considered out-with normal limits for wild birds. It is possible that the empty gizzards were a result of the respiratroy disease rather than a cause of it. There was histological evidence of infestation with Syngamus trachea in one bird (bird 10, see table 2), diagnosed with caseous airsacculitis. Parasitic bronchitis may have predisposed to opportunistic bacterial infection (E. coli, not P. multocida, was isolated) in this bird. However, in general, parasitism was not considered a major factor in this disease outbreak. Of the Mycoplasma species isolated only M. sturni has been reported to be of pathological significance, being associated initially with conjunctivitis in songbirds in the USA (Ley et al., 1998). In Europe it is associated with a range of clinical signs, though not conjunctivitis (Pennycott et al., 2005). In common with the latter study, M. sturni-positive birds in the present report were not suffering from conjunctivitis, and the significance of mycoplasma carriage remains unclear.

The pig unit was closed down during the submission period and before samples could be obtained, consequently it was not possible to investigate whether commensal carriage of P. multocida by pigs on this unit contributed to the epidemiology of the disease. However, serogroup F is rarely isolated in this species (Rimler \& Brogden 1986, Pijoan 2006), making a link with the observed disease in corvids unlikely. 
On the basis of the findings reported here, P. multocida infection should be considered as a major differential diagnosis for respiratory disease in wild corvids, the diagnostic rate will be enhanced by the use of IHC for P. multocida in such investigations, especially in those birds submitted dead. Additionally, corvids may act as a reservoir of $P$. multocida for infections in domestic poultry.

\section{Acknowledgments}

The authors thank Steven Newlove (owner of the outdoor pig unit) for his diligence and co-operation and Clare Underwood and Jeanie Finlayson (MRI) for expert preparation of histological and immunohistochemical sections. MPD, CWB and JCH are funded by the Scottish Government. The Wildlife Incident Investigation Scheme (WIIS) is funded by Defra. Some work was funded by the Scanning Surveillance VLA Diseases in Wildlife Scheme (ED1600), funded by Defra's food and farming group (FFG). 


\section{References}

Anon. (2006). Diagnostic manual for Avian Influenza, Ch. VI, Molecular tests and evaluation of results. Official Journal of the European Union, 49, L237/1-L237/27. At: http://eurlex.europa.eu/LexUriServ/site/en/oj/2006/1_237/1_23720060831en00010027.pdf

Anon. (2010a) Commission Decision on the implementation by member states of surveillance programmes for avian influenza in poultry and wild birds. Annex II, Part 1: Guidelines on the implementation of surveillance programmes for avian influenza in wild birds. Official Journal of the European Union, 53, L166/22-L166/32. At: http://faolex.fao.org/docs/pdf/eur96321.pdf

Blackall, P. \& Norskov-Lauritsen, N. (2008) Pasteurellaceae- the view from the diagnostic laboratory. In P. Kuhnert \& H. Christensen (Eds.). Pasteurellaceae Biology, Genomics and Molecular Aspects (pp. 227-261). Pasteurellaceae, Biology, genomics and molecular aspects. Norfolk: Caister Acad. Press.

Bradbury, J.M. (1998). Recovery of mycoplasmas from birds. In R. Miles \& R.A.J, Nicholas (Eds). Mycoplasma Protocols (pp. 37-44). Totowa: Humana Books.

Brown, P.M., Turnbull, G., Charman, S., Charlton A.J.A. \& Jones, A. (2005). Analytical methods used in the United Kingdom Wildlife Incident Scheme for the detection of animal poisoning by pesticides. Journal of the Association of Official Analytical Chemists (AOAC), 1, 204-220.

Christensen, J.P. \& Bisgaard, M. (2000). Fowl Cholera. Revue scientifique et technique (International Office of Epizootics), 19, 626-637.

Dagleish, M.P., Finlayson, J., Bayne, C., MacDonald, S., Sales, J. \& Hodgson, J.C. (2010). Characterisation and time course of pulmonary lesions in calves after intratracheal 
challenge with Pasteurella multocida A:3. Journal of Comparative Pathology, 142, 157-169.

Dziva, F., Muhhairwa, P., Bisgaard, M. \& Christensen, H. (2008) Diagnostic and typing options for investigating diseases associated with Pasteurella multocida. Veterinary Microbiogy, 128, 1-22.

Ewers, C., Lübke-Becker, A., Bethe, A., Kiebling, S., Filter, M. \& Wieler, L.H. (2006). Virulence genotype of Pasteurella multocida strains isolated from different hosts with various disease status. Veterinary Microbiology, 31, 304-317.

Glisson, J.R, Hofacres, C.L \& Christensen, J.P. (2008). Fowl Cholera. In Y.M. Saif (Ed). Diseases of Poultry, 12 ${ }^{\text {th }}$ Edition (pp. 739-758). Ames: Blackwell Publishing.

Gough, R.E., Alexander, D.J., Collins, M.S., Lister,S.A. \& Cox, W.J. (1998). Routine virus isolation or detection in the diagnosis of diseases of birds. Avian Pathology, 17, 893907.

Keymer, I.F. (1958). A survey and review of the causes of mortality in British birds and the significance of wild birds as disseminators of disease. The Veterinary Record, 70, 713720.

Ley, D.H., Geary, S.J., Berkhoff, J.E., McLaren, J.M., \& Lavisohn, S. (1998). Mycoplasma sturni from Blue Jays and Northern Mockingbirds with conjunctivitis in Florida. Journal of Wildlife Diseases, 34, 403-406.

Lichtensteiger, C.A., Steenbergen, S.M., Lee, R.M., Polson, D.D. \& Vimr, E.R. (1996)

Direct PCR Analysis for Toxigenic Pasteurella multocida. Journal of Clinical Microbiology, 37, 3035-3039

Marchant, J. H \& Gregory, R. D. (1999). Number of nesting rooks Corvus frugilegus in the United Kingdom in 1996. Bird Study, 46, 258-273. 
McAuliffe, L., Ellis, R., Lawes, J., Ayling, R.D. and Nicholas, R.A.J. (2005). 16S rDNA and DGGE: a single generic test for detecting and differentiating Mycoplasma species. Journal of Medical Microbiology, 54, 1-9.

McDiarmid, A. (1965). Modern trends in animal health and husbandry, some infectious diseases of free-living wildlife. British Veterinary Journal, 121, 245-257.

Murray, K.O., Mertens, E. \& Despres, P. (2010) West Nile Virus and its emergence in the United Ststes of America. Veterinary Research, 41, 67-81

Ogunnariwo, J.A., \& Schryvers, A.B. (2001). Characterization of a Novel Transferrin Receptor in Bovine Strains of Pasteurella multocida. Journal of Bacteriology, 183, 890-896.

Papa, A., Danis, K., Bakas, A., Douglas, G. Lytras, T., Theocharopoilos, G., Chrysagis, D., Vassiliadou, E., Kamaria, F., Liona, A., Mellou, K., Saroglou, G. \& Panagiotopoulos, T. (2010) Ongoing outbreak of West Nile virus infections in humans in Greece, JulyAugust 2010. Euro Surveillance, 15, 19644. At: http://www.eurosurveillance.org/images/dynamic/EE/V15N34/art19644.pdf

Pennycott, T.W., Dare, C.M, Yavari, C.A \& Bradbury, J.M. (2005). Mycoplasma sturni and Mycoplasma gallisepticum in wild birds in Scotland. The Veterinary Record, 156, 513515.

Pennycott, T.W. (2005). SAC October 2005 Monthly Report. www.sac.ac.uk/consultancy/veterinary/publications/monthlyreports/2005/oct/

Petersen, K.D, Christensen, J.P, Permin, A. \& Bisgaard, M. (2001). Virulence of Pasteurella multocida subsp. Multocida from outbreaks of fowl cholera in wild birds for domestic poultry and game birds. Avian Pathology, 30, 27-31. 
Phipps, L.P., Gough, R.E., Ceeraz, V., Cox, W.J. \& Brown, I.H. (2007) Detection of West Nile Virus in tissues of specific pathogen free chickens and serological response to laboratory infection: a comparative study. Avian Pathology, 36, 301-305.

Pijoan, C. (2006) Pneumonic pasteurellosis. In B. Straw, J.J. Zimmerman, S. D’ Allaire \& D. Taylor (Eds.). Diseases of Swine, $9^{\text {th }}$ Edition (pp. 719-726), Ames: Blackwell Publishing.

Reisen, W. K, Barker, C.M., Carney, R., Lothrop, H.D., Wheeler, S.S., Wilson, J.L., Madon, M.B., Takahashi, R., Carroll, B., Garcia, S., Fang, Y., Shafii, M., Kahl, N., Ashtari, S., Kramer, V., Glaser, C. \& Jean, C. (2006). Role of corvids in Epidemiology of West Nile Virus in Southern California. Journal of Medical Entomology, 43, 356-367.

Rhoades, K.R. \& Rimler, R.B. (1990). Somatic serotypes of Pasteurella multocida strain isolated from avian hosts (1976-1988). Avian Diseases, 34, 193-195.

Rimler, R.B. and Glisson, J.R. (1997). Fowl cholera. In B.W. Calnek, H.J. Barnes, C.W. Beard, L.R. McDougald, \& Y.M. Sail (Eds.). Diseases of Poultry 10th edn (pp.143161). Ames: Iowa State University Press.

Rimler, R.B. \& Brogden, K.A. (1986) Pasteurella multocida isolated from rabbits and swine: Serologic types and toxin production. American Journal of Veterinary Research, 47, $730-736$.

Shivachandra, S. B., Kumar, A. A., Gautam, R., Singh, V. P., Saxena, M. K. \& Srivastava, S. K. (2006) Identification of avian strains of Pasteurella multocida in India by conventional and PCR assays. The Veterinary Journal, 172, 561-564.

Snipes, K.P., Carpenter, T.E., Corn, J.L., Kasten, R.W., Hirsh, D.C., Hird, D.W., \& McCapes, R.H. (1988) Pasteurella multocida in wild mammals and birds in California: prevalence and virulence for turkeys. Avian Diseases, 32, 9-15. 
Taylor, T.T. \& Pence, D.B. (1981). Avian cholera in common crows, Corvus brachyrhynchos, from the central Texas panhandle. Journal of Wildlife Diseases, 17, $511-514$.

Townsend, K.M., Boyce, J.D., Chung, J.Y., Frost, A.J. \& Adler, B. (2001). Genetic organization of Pasteurella multocida cap loci and development of a multiplex capsular pcr typing system. Journal of Clinical Microbiology, 39, 924-929.

Townsend, K. M., Frost, A. J., Lee, C. W., Papadimitriou, J. M. \& Dawkins, H. J. (1998). Development of PCR assays for species- and type-specific identification of Pasteurella multocida isolates. Journal of Clinical Microbiology, 36, 1096-1100.

Zinkl, J.G., Dey, N., Hyland, J.M., Hurt, J.J. \& Heddleston, K.L. (1977). An epornitic of avian cholera in waterfowl and common crows in Phelps county, Nebraska, in the spring, 1975. Journal of Wildlife Diseases, 13, 194-198.

Zoller, H., Lenglet, A., \& Van Bortel, W. (2010) West Nile Virus: The need to strengthen preparedness in Europe. Euro Surveillance, 15, 19647.

http://www.eurosurveillance.org/ViewArticle.aspx?ArticleId=19647 


\begin{tabular}{|c|c|c|c|c|c|c|c|c|c|}
\hline Sub & Bird & Sp. & $\begin{array}{l}\text { Live/ } \\
\text { Dead }\end{array}$ & Clinical Signs & Gross Pathology & $\begin{array}{l}\text { Microbiology } \\
\text { Tissue Samples }\end{array}$ & Routine Cultures & Fungal Cultures & Mycoplasma Cultures/ ID \\
\hline \multirow{7}{*}{1} & 1 & $\mathrm{CF}$ & \multirow{7}{*}{ Dead } & \multirow{7}{*}{ FD } & & Lung & & ND & - \\
\hline & 2 & $\mathrm{CF}$ & & & Severe autolysis (all). & Lung, AS & & ND & - \\
\hline & 3 & $\mathrm{CF}$ & & & Fibrinous airsacculitis (4 birds). & Pericardium & All overgrown with & - & - \\
\hline & 4 & $\mathrm{CF}$ & & & Fibrinous perihepatitis ( 2 birds). & Heart blood & Proteus & - & - \\
\hline & 5 & $\mathrm{CF}$ & & & Severe fibrinous pericarditis (2 birds). & Liver & & - & - \\
\hline & 6 & $\mathrm{CF}$ & & & Necrotic pneumonia (2 birds). & AS & & & - \\
\hline & 7 & $\mathrm{CF}$ & & & & - & - & - & - \\
\hline \multirow{2}{*}{2} & \multirow{2}{*}{8} & \multirow{2}{*}{$\mathrm{CF}$} & \multirow{2}{*}{ Live } & Severe dyspnoea, & Fibrinopurulent airsacculitis. & $\begin{array}{c}\text { AS } \\
\text { Sinus }\end{array}$ & $\begin{array}{c}\text { Pure PM } \\
\text { Mixed includino PM }\end{array}$ & ND & M. sturni \\
\hline & & & & $\begin{array}{l}\text { paresis, mucoid } \\
\text { discharge sinuses }\end{array}$ & $\begin{array}{l}\text { Purulent pneumonia. } \\
\text { Mucopurulent Sinusitis. }\end{array}$ & $\begin{array}{l}\text { Sinus } \\
\text { Liver }\end{array}$ & $\begin{array}{l}\text { Mixed including PM } \\
\text { No growth }\end{array}$ & $\begin{array}{l}\mathrm{ND} \\
-\end{array}$ & - \\
\hline \multirow{3}{*}{3} & \multirow{3}{*}{9} & \multirow{3}{*}{$\mathrm{CC}$} & \multirow{3}{*}{ Live } & \multirow{3}{*}{$\begin{array}{l}\text { Snicking cough } \\
\text { and severe } \\
\text { dyspnoea }\end{array}$} & \multirow{4}{*}{$\begin{array}{l}\text { Gritty fibrinous airsacculitis. } \\
\text { Sero-fibrinous pericarditis }\end{array}$} & Lung & Pure PM & ND & M. sturni \\
\hline & & & & & & AS & Pure PM & ND & M. gallopavonis \\
\hline & & & & & & Heart blood & Pure PM & - & - \\
\hline \multirow[b]{3}{*}{4} & & & & & & Liver & Pure PM & - & - \\
\hline & 10 & $\mathrm{CC}$ & Dead & FD & Caseous airsacculitis. & $\begin{array}{l}\text { Lung } \\
\text { AS }\end{array}$ & $\begin{array}{l}\text { No growth } \\
\text { E. coli }\end{array}$ & ND & ND \\
\hline & 11 & $\mathrm{CC}$ & Live & $\begin{array}{l}\text { Reduced flying } \\
\text { ability (able to be } \\
\text { caught) }\end{array}$ & Necrotic plaques on air sacs. & Lung & $\begin{array}{c}\text { PM } \\
\text { No growth }\end{array}$ & ND & $\begin{array}{l}\text { M. gallinarum } \\
\text { M. gallopavonis } \\
\text { M. sturni } \\
\text { (pooled Lung \&AS) }\end{array}$ \\
\hline \multirow{2}{*}{5} & \multirow{2}{*}{12} & \multirow{2}{*}{$\mathrm{CF}$} & \multirow{2}{*}{ Live } & \multirow{2}{*}{$\begin{array}{l}\text { Died while in } \\
\text { trap, poor flight, } \\
\text { severe dyspnoea }\end{array}$} & $\begin{array}{c}\text { Focal necrotic pneumonia. } \\
\text { Generalised fibrinous airsacculitis. }\end{array}$ & Lung & PM and Proteus & ND & M. columborale \\
\hline & & & & & $\begin{array}{l}\text { Mild fibrinous perihepatitis. } \\
\text { Mild fibrinous pericarditis. }\end{array}$ & AS & Pure PM & ND & Unidentified Mycoplasma \\
\hline \multirow{2}{*}{6} & \multirow{2}{*}{13} & \multirow{2}{*}{$\mathrm{CC}$} & \multirow{2}{*}{ Dead } & \multirow{2}{*}{ FD } & \multirow{2}{*}{$\begin{array}{l}\text { Severe fibrinous pericarditis. } \\
\text { Severe fibrino-purulent airsacculitis. } \\
\text { Purulent pneumonia. }\end{array}$} & Lung & Proteus & ND & M. sturni \\
\hline & & & & & & AS & Proteus & ND & M. sturni \\
\hline 7 & 14 & $\mathrm{CC}$ & Live & Mild respiratory & Mild fibrinous airsacculitis. & Lung & Pure PM & ND & ND \\
\hline 1 & 14 & $c$ & Live & signs & Focal pneumonia. Mild pericarditis. & Pericardium & Pure PM & - & ND \\
\hline 8 & 15 & $\mathrm{CC}$ & Live & Dropped wing & Simple fracture left humerus. & Liver, lung & No growth & ND & ND \\
\hline & 16 & $\mathrm{CC}$ & Dead & FD & $\begin{array}{l}\text { Diffuse fibrinous airsacculitis. } \\
\text { Mild fibrinous pericarditis. }\end{array}$ & $\begin{array}{l}\text { Lung } \\
\text { AS }\end{array}$ & $\begin{array}{l}\text { E. coli only } \\
\text { No growth }\end{array}$ & $\begin{array}{l}\text { ND } \\
\text { ND }\end{array}$ & ND \\
\hline 9 & 17 & $\mathrm{CC}$ & Dead & FD & $\begin{array}{c}\text { Multifocal beige necrotic lesions up } \\
\text { to } 2 \mathrm{~mm} \text { in diameter throughout liver } \\
\text { parenchyma. } \\
\text { Hepatomegaly. Splenomegaly }\end{array}$ & $\begin{array}{l}\text { Lung } \\
\text { Liver }\end{array}$ & No growth & ND & ND \\
\hline & & & & & Focal fibrinous perihepatitis. & Lung & No growth & ND & \\
\hline & 18 & $\mathrm{CC}$ & Dead & FD & $\begin{array}{l}\text { Multifocal petechiation of distal } \\
\text { intestine. }\end{array}$ & Liver & No growth & - & ND \\
\hline
\end{tabular}

Table 1.Summary of clinical signs, gross pathology and bacteriological findings from this case series $. \mathrm{CC}=$ Corvus corone $; \mathrm{CF}=$ Corvus frugilegus; $\mathrm{AS}=\mathrm{Air}$ sacs; $\mathrm{ND}=\mathrm{Not}$ detected; - = Not done; FD = Found dead; Sub= submission number; PM = Pasteurella multocida 


\begin{tabular}{|c|c|c|c|c|c|c|c|}
\hline $\begin{array}{l}\text { Bird } \\
\text { No. }\end{array}$ & Status & Species & $\begin{array}{l}\text { Tissues taken } \\
\text { for } \\
\text { histopathology }\end{array}$ & $\begin{array}{l}\text { Pneumonia/ } \\
\text { air } \\
\text { sacculitis }\end{array}$ & $\begin{array}{l}\text { IHC } \\
\text { lung/ } \\
\text { air } \\
\text { sacs }\end{array}$ & $\begin{array}{l}\text { Pulmonary } \\
\text { parasites }\end{array}$ & Comments \\
\hline $1-7$ & dead & All CF & $\begin{array}{l}\text { lung, air sac, } \\
\text { liver, heart \& } \\
\text { brain }\end{array}$ & $\begin{array}{l}\text { extensive } \\
\text { necrotising } \\
\text { fibrino- } \\
\text { granulocytic }\end{array}$ & + & $\begin{array}{c}+ \\
\text { nematode }\end{array}$ & $\begin{array}{l}\text { severe autolysis (all), } \\
\text { multiple granulomatous } \\
\text { foci in the liver (birds } 1,2 \\
\& 3 \text { ), fibrinous } \\
\text { pericarditis (bird } 4 \text { ) }\end{array}$ \\
\hline 8 & live & $\mathrm{CF}$ & lung & $\begin{array}{l}\text { severe } \\
\text { fibrino- } \\
\text { granulocytic }\end{array}$ & + & - & none \\
\hline 9 & live & $\mathrm{CC}$ & $\begin{array}{c}\text { lung, air sac, } \\
\text { spleen, bursa, } \\
\text { liver, kidney \& } \\
\text { heart }\end{array}$ & $\begin{array}{l}\text { severe } \\
\text { fibrino- } \\
\text { granulocytic }\end{array}$ & + & $\begin{array}{c}+ \\
\text { nematode }\end{array}$ & granulocytic foci in liver \\
\hline 10 & dead & $\mathrm{CC}$ & $\begin{array}{l}\text { lung, air sac, } \\
\text { liver, kidney, } \\
\text { spleen \& brain }\end{array}$ & $\begin{array}{l}\text { granulocytic } \\
\text { foci }\end{array}$ & + & $\stackrel{+}{+}$ & mineralised foci in liver \\
\hline 11 & live & $\mathrm{CC}$ & $\begin{array}{l}\text { lung, air sac, } \\
\text { liver, bursa, } \\
\text { spleen \& brain }\end{array}$ & $\begin{array}{l}\text { necrotising } \\
\text { fibrino- } \\
\text { granulocytic }\end{array}$ & + & - & suppurative foci in liver \\
\hline 12 & live & $\mathrm{CF}$ & $\begin{array}{c}\text { lung, air sac \& } \\
\text { heart }\end{array}$ & $\begin{array}{l}\text { severe } \\
\text { fibrino- } \\
\text { granulocytic }\end{array}$ & + & - & $\begin{array}{l}\text { myxomatous changes in } \\
\text { myocardium adjacent to } \\
\text { heart valves }\end{array}$ \\
\hline 13 & dead & $\mathrm{CC}$ & none & N/A & N/A & N/A & $\begin{array}{l}\text { whole carcase sent for } \\
\text { Mycoplasma testing }\end{array}$ \\
\hline 14 & live & $\mathrm{CC}$ & lung & $\begin{array}{l}\text { localised } \\
\text { fibrino- } \\
\text { granulocytic }\end{array}$ & - & $\stackrel{+}{+}+$ & $\begin{array}{l}\text { trematode parasite in } \\
\text { bronchi at centre of } \\
\text { localised pneumonia }\end{array}$ \\
\hline 15 & live & $\mathrm{CC}$ & $\begin{array}{l}\text { lung, brain, } \\
\text { spleen \& liver }\end{array}$ & $\begin{array}{l}\text { No } \\
\text { significant } \\
\text { lesions }\end{array}$ & - & $\begin{array}{c}+ \\
\text { nematode }\end{array}$ & $\begin{array}{l}\text { mild non-suppurative } \\
\text { cholangiohepatitis }\end{array}$ \\
\hline 16 & dead & $\mathrm{CC}$ & lung \& heart & none found & $+/-$ & - & none \\
\hline 17 & dead & $\mathrm{CC}$ & lung & $\begin{array}{l}\text { small } \\
\text { necrotic } \\
\text { focus }\end{array}$ & + & & $\begin{array}{l}\text { acute necrotising } \\
\text { splenitis, suppurative } \\
\text { hepatitis both IHC } \\
\text { negative }\end{array}$ \\
\hline 18 & dead & $\mathrm{CC}$ & $\begin{array}{l}\text { lung, liver \& } \\
\text { spleen }\end{array}$ & $\begin{array}{l}\text { small } \\
\text { granulomat } \\
\text { ous focus }\end{array}$ & + & - & $\begin{array}{l}\text { multifocal necrotic } \\
\text { hepatitis }\end{array}$ \\
\hline
\end{tabular}

Table 2 : Histological lesions present and immunohistochemistry results in birds available for examination

$(\mathrm{CF}=$ rook, $\mathrm{CC}=$ carrion crow, $\mathrm{N} / \mathrm{A}=$ not available,$+=$ positive labelling $/$ presence of parasites,$-=$ no

labelling/presence of parasites, +/- = inconclusive result). *Likely Syngamus trachea 


\section{Figure Legends}

Figure 1. Gross lesions of fibrino-purulent air sacculitis (bird 8) typical of those found in many of the birds submitted. Note presence of fibrin and caseous deposits on surface of air sacs and lungs.

Figure 2. Severe necrotic pneumonia, confirmed histologically, in an ex situ lung sample from bird 12, which died after capture and suffering from clinical signs of poor flight and dyspnoea. This bird's carcase was fresh and not autolysed.

Figure 3. Histological preparation of lung (bird 12) showing severe fibrino-granulocytic pneumonia with areas of necrosis (arrows) (haematoxylin and eosin).

Figure 4a. Immunohistochemical preparation labelling Pasteurella multocida (brown pigment) in lung tissue. Note large areas of labelled bacteria (black arrows) surrounded by granulocytes (blue arrows) (counter- stained with haematoxylin).

Figure 4b. Higher power image showing immunolabelling (brown pigment) of $\mathrm{P}$. multocida within the cytoplasm of macrophages (arrows) within the lung (counter-stained with haematoxylin). 


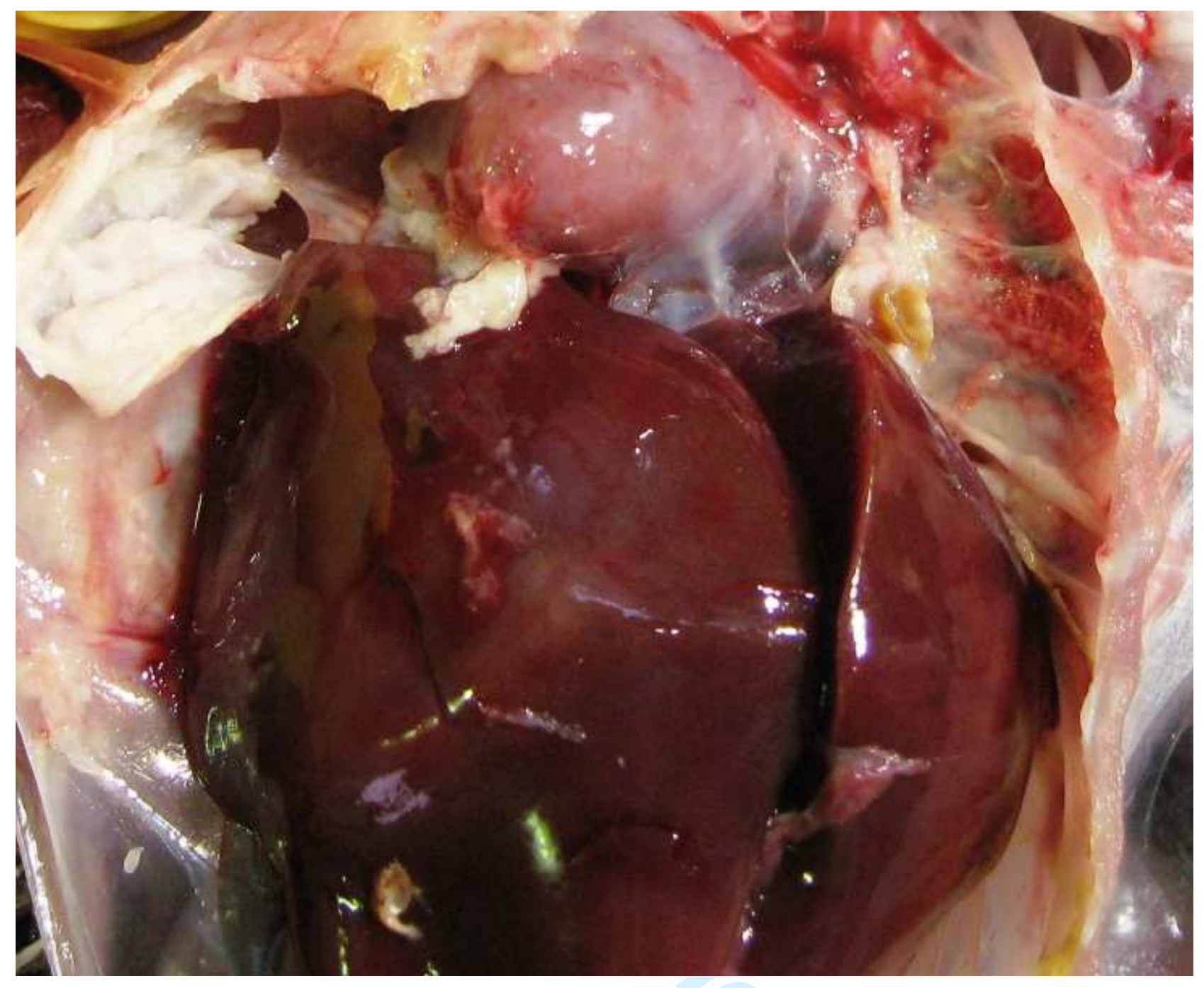

Fig 1 


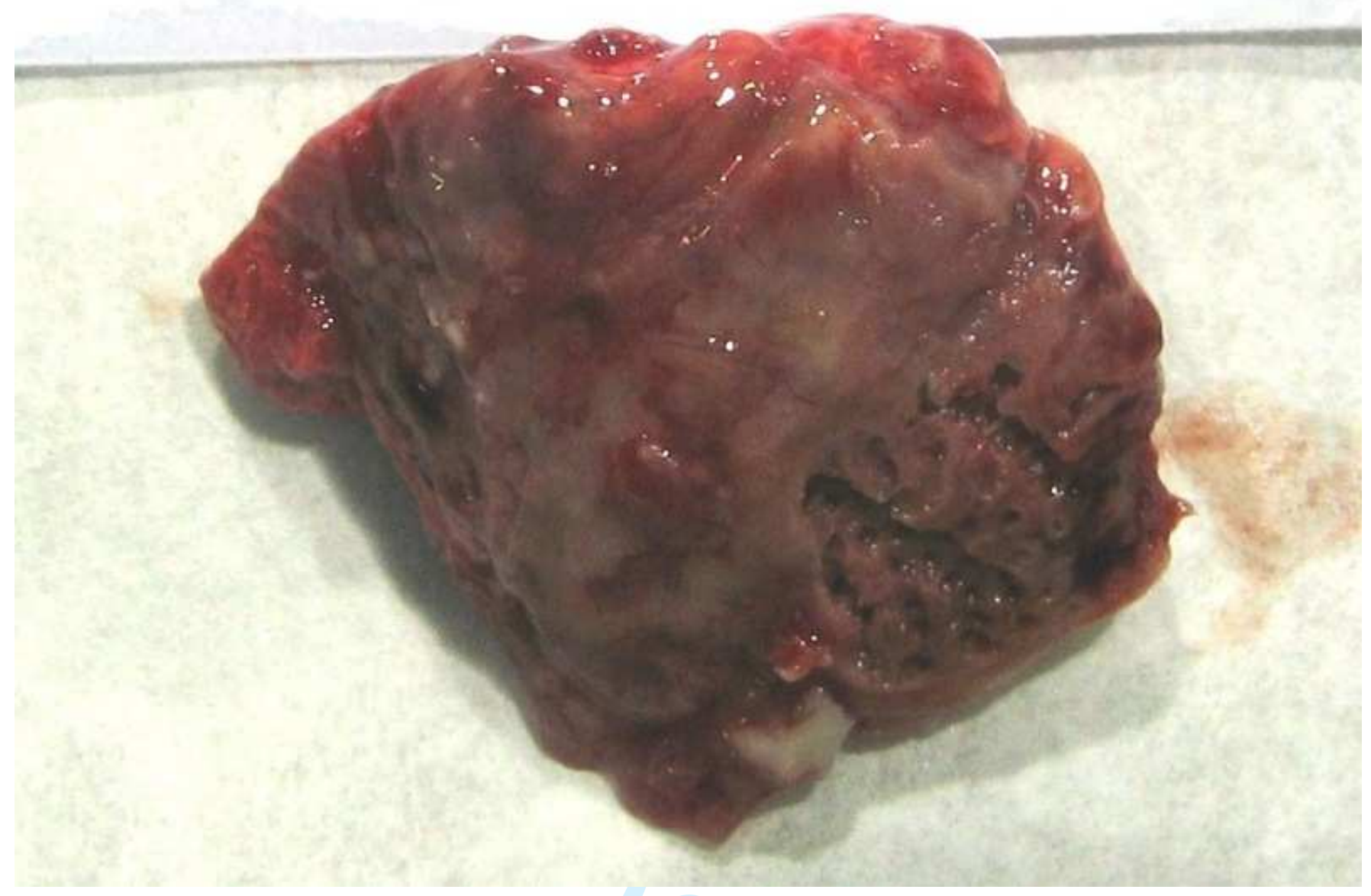

Fig 2 


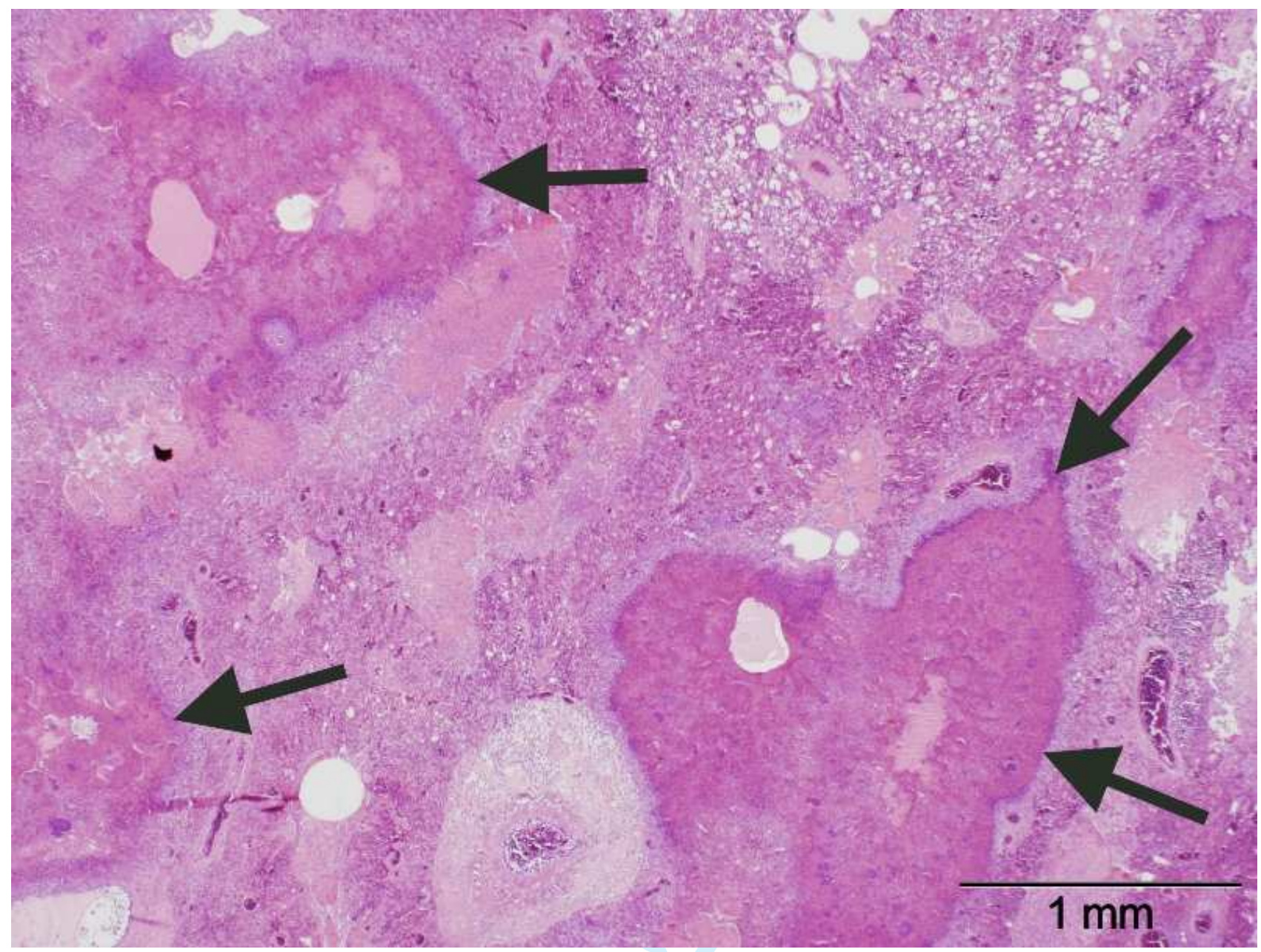

Fig 3 


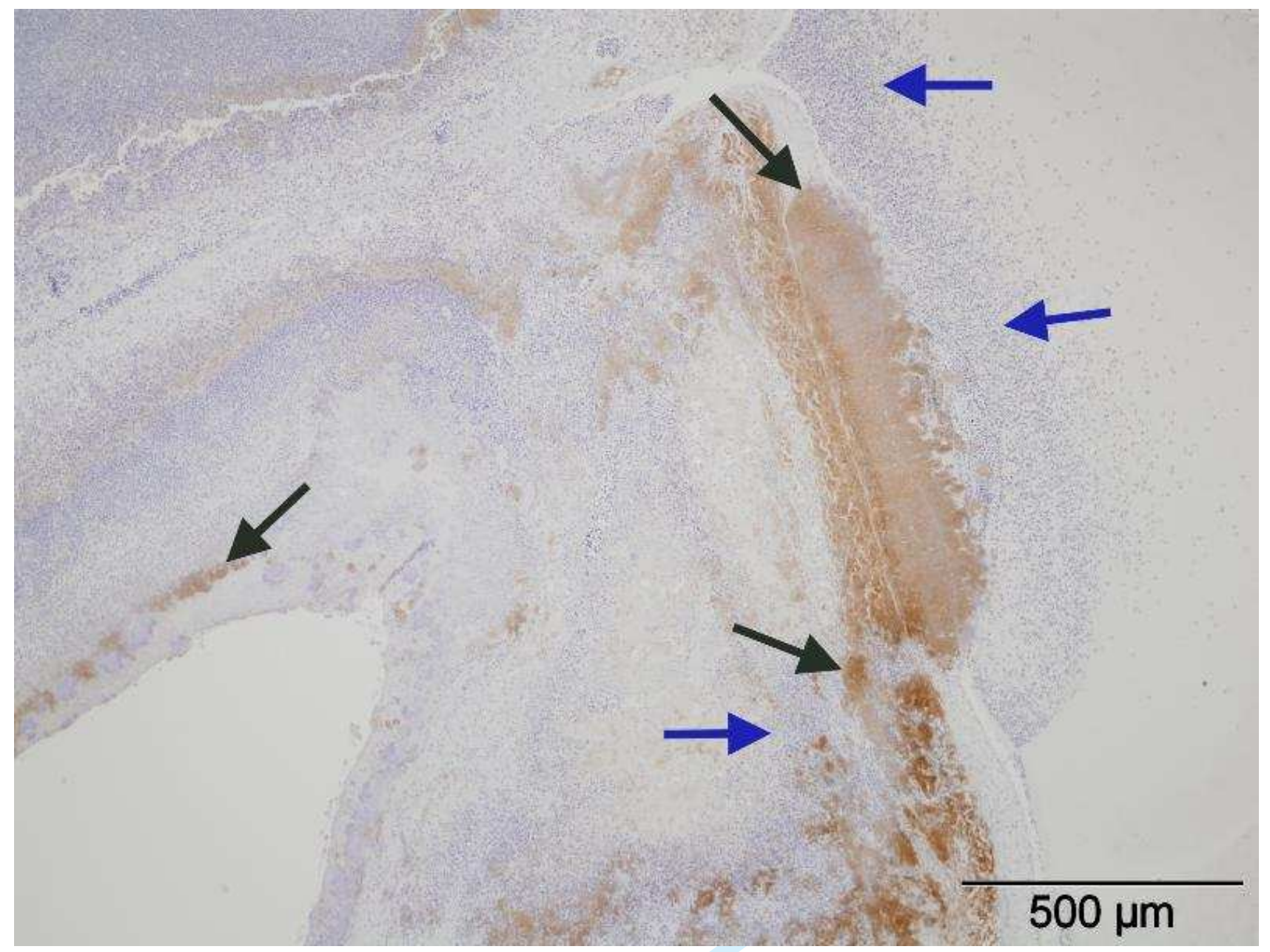

Figure $4 \mathrm{a}$ 


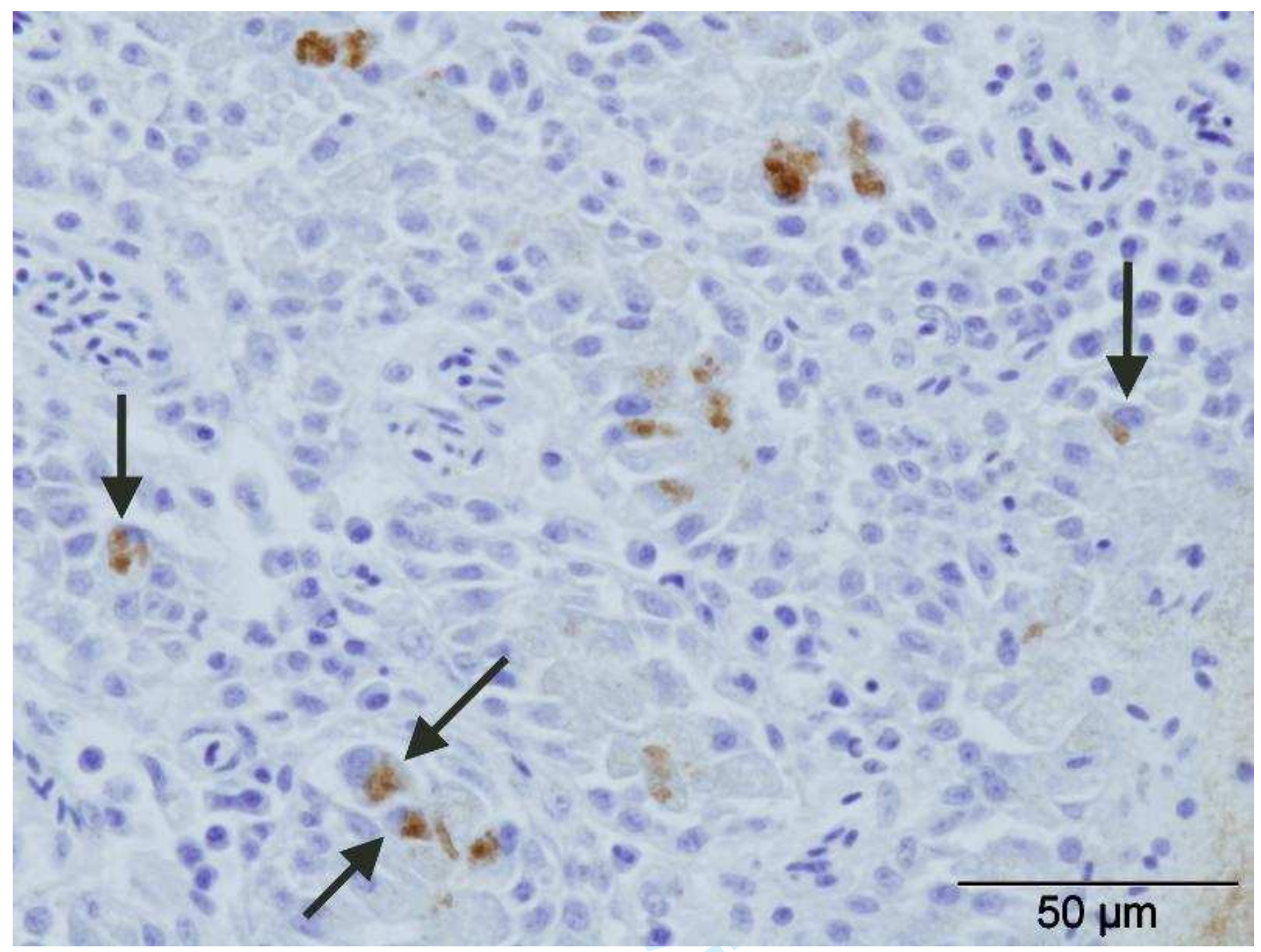

Figure $4 b$. 